\title{
AGE DETERMINATION OF THE KAWAGODAIRA VOLCANIC ERUPTION IN JAPAN BY ${ }^{14} \mathrm{C}$ WIGGLE-MATCHING
}

\author{
Sayaka Tani ${ }^{1}$ Hiroyuki Kitagawa ${ }^{1,2} \bullet$ Wan Hong $^{3} \bullet$ Jung Hun Park ${ }^{3}$ Ki Suk Sung ${ }^{3}$ Gyujun Park ${ }^{3}$ \\ ABSTRACT. The Kawagodaira Volcano is located on the northwest slope of Amagi Volcano on the Izu Peninsula of central \\ Japan. The fine pumice that erupted from Kawagodaira Volcano is widely distributed in the central and western parts of the \\ Japanese mainland. Here, we report an accurate eruption age determined by radiocarbon wiggle-matching of a Japanese cedar \\ timber excavated from the pyroclastic deposit at the pumice flow terminal of Kawagodaira Volcano. The ${ }^{14} \mathrm{C}$ wiggle-match \\ estimate for the Kawagodaira Volcano eruption is $1210-1187$ cal BC (95.4\% confidence level).
}

\section{INTRODUCTION}

A volcanic pumice deposition (or ash layer) provides valuable information for estimating the correlations of geological and archaeological records. Kawagodaira Volcano is located on the northwest slope of Mt Amagi in Izu Peninsula, central Japan (Figure 1). The pumice that erupted from the volcano is important for the dating of archaeological remains of the Jomon culture around Izu Peninsula. The fine, white pumice deposition is also distributed several hundred kilometers away and has frequently been observed in archaeological and paleoenvironmental (natural) sites in the central and western parts of the Japanese mainland (Machida and Arai 1992). The thin layer of pumice in lake and land sediment cores has often been used for determining chronological correlations independently of radiometric dating (Takemura et al. 1994, 2010).

The eruption of Kawagodaira Volcano has been dated using ${ }^{14} \mathrm{C}$ for almost $60 \mathrm{yr}$. The first ${ }^{14} \mathrm{C}$ date to be determined was reported in 1963 (2830 \pm 120 BP, Gak-253; Kigoshi and Endo 1963). Since then, more than $50{ }^{14} \mathrm{C}$ dates relating to the eruption age have been published. Yet these ${ }^{14} \mathrm{C}$ data are widely scattered in a range from 2700 to $3400 \mathrm{BP}$. The calibrated ages are scattered even more widely, from 800 to $1770 \mathrm{BC}$, because of plateaus in the ${ }^{14} \mathrm{C}$ calibration curve over parts of this time interval. The eruption age still remains controversial and inconclusive. We report herein an accurate age obtained by ${ }^{14} \mathrm{C}$ wiggle-matching of a Japanese cedar timber excavated from a pyroclastic flow deposit of Kawagodaira Volcano.

\section{MATERIALS AND METHODS}

The eruptive activity of Kawagodaira Volcano has been divided into 4 continuous stages (Shimada 2000): pyroclastic surge eruption (stage I); Plinian eruption (stage II); pyroclastic flow eruption (stage III); and lava extrusion (stage IV). In stage II, the fine pumice was erupted and distantly transported by easterly winds (probably in the summer). In 1982, a standing timber of fossil Japanese cedar with slightly carbonized bark was excavated from a pyroclastic flow deposit (stage III) at the Ikadaba site $\left(34.897^{\circ} \mathrm{N}, 138.969^{\circ} \mathrm{E}\right)$ on the northern slope of Kawagodaira Volcano (Kg sample ID).

The outer part of a 1.6-m-diameter log with 350 tree rings was divided into 5 -yr blocks from the outermost ring. In general, Japanese cedar has clear tree rings that are easily identified, even by a nonspecialist in dendrochronology. The tree rings of sample $\mathrm{Kg}$ were typically $0.5-1.5 \mathrm{~mm}$ thick and were circumferentially traceable, making it easier to identify false rings.

\footnotetext{
${ }^{1}$ Graduate School of Environmental Studies, Nagoya University, Japan.

${ }^{2}$ Corresponding author. Email: hiroyuki.kitagawa@nagoya-u.jp.

${ }^{3}$ Korea Institute of Geoscience and Mineral Resources (KIGAM), Korea.
} 


\section{S Tani et al.}

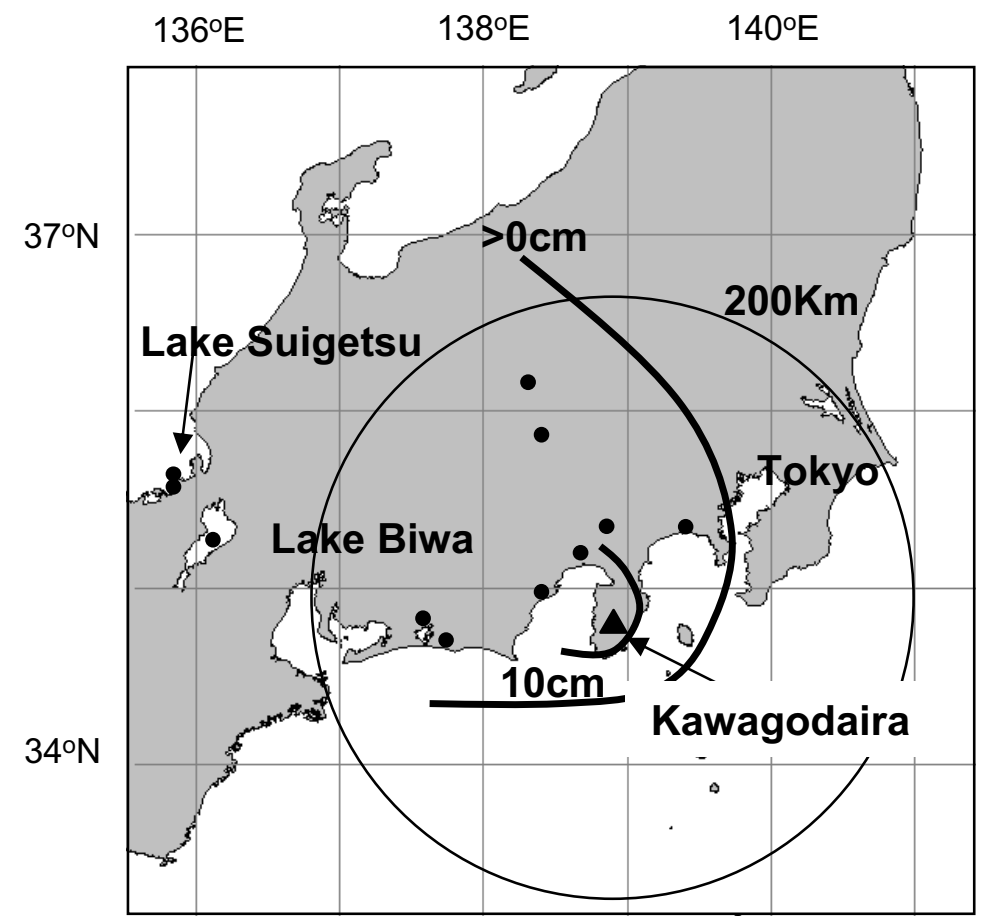

Figure 1 Geological map of Amagi Volcano showing the sample collection site and the spatial distribution of the pumice deposition from the Kawagodaira eruption (modified after Machida and Arai 1992; Shimada 2000).

To obtain accurate data and validate the sample preparation and accelerator mass spectrometry (AMS) measurement, all 28 blocks were prepared and dated twice. Crushed fragments of each block were treated with a standard acid-alkali-acid (AAA) method at Nagoya University. The AAAtreated samples were further breached with a sodium chlorite $\left(\mathrm{NaClO}_{2}\right)$ and hydrochloric acid $(\mathrm{HCl})$ mixture to obtain holo-cellulose. Cellulose samples of about $5 \mathrm{mg}$ were repeatedly washed by hot Milli-Q ${ }^{\mathrm{TM}}$ water, dried under a vacuum, vacuum-sealed in $9-\mathrm{mm}$ preheated quartz tubes together with copper oxide wire, and heated at $850{ }^{\circ} \mathrm{C}$ for about $2 \mathrm{hr}$. The $\mathrm{CO}_{2}$ was then cryogenically separated, and a portion of about $1.2 \mathrm{mg}$ carbon was reduced to graphite at $600{ }^{\circ} \mathrm{C}$ in the presence of hydrogen gas and catalytic iron powder. The graphite was pressed into an aluminum cathode for AMS measurement, and the ${ }^{14} \mathrm{C} /{ }^{12} \mathrm{C}$ and ${ }^{13} \mathrm{C} /{ }^{12} \mathrm{C}$ ratios were measured by a $1 \mathrm{MV}$ AMS system at the Korea Institute of Geoscience and Mineral Resources, KIGAM (Hong et al. 2010).

${ }^{14} \mathrm{C}$ ages of the samples were calculated from the measured ${ }^{14} \mathrm{C} /{ }^{12} \mathrm{C}$ ratios after correcting for isotope fractionation by normalizing the ${ }^{13} \mathrm{C} /{ }^{12} \mathrm{C}$ ratios (measured by AMS) to $\delta^{13} \mathrm{C}=-25 \%$ (Stuiver and Polach 1977). The error was evaluated by identifying statistical errors in the ${ }^{14} \mathrm{C}$ counts for sample, 6 oxalic acid standards (HOxII) and processed blanks, and for random machine error. The random machine error (typically $0.3 \%$ ) was determined by measurements of 6 oxalic acid standards in each run. Blank correction was evaluated using measurements of a ${ }^{14} \mathrm{C}$-free wood reference processed in the same manner at Nagoya University. The blank-corrected value was lower than $0.3 \%$ of modern carbon. The calendar year of the Kawagodaira volcanic eruption was determined using the Bayesian wiggle-matching program OxCal v 4.1 (Bronk Ramsey et al. 2004; Bronk Ramsey 2009) and the Northern Hemisphere calibration curve IntCal09 (Reimer et al. 2004). 


\section{RESULTS AND DISCUSSION}

The AMS ${ }^{14} \mathrm{C}$ ages of the sample $\mathrm{Kg}$ are listed in Table 1. The weighted mean of $2{ }^{14} \mathrm{C}$ ages from each block was calculated for ${ }^{14} \mathrm{C}$ wiggle-matching, except for $\mathrm{Kg} 11$. The significance of a pairsample $t$ test of 2 data sets is much higher than that at the $p=0.05$ level, suggesting no significant differences between 2 batches of laboratory pretreatment and AMS analysis. A statistical difference at the $p=0.05$ level $\left(\chi^{2}=3.82\right)$ for sample $\mathrm{Kg} 11$ was observed (critical value of $\left.\chi^{2}=3.87, p=0.05\right)$. These data were omitted for the ${ }^{14} \mathrm{C}$ wiggle-match age determination. A total of $27{ }^{14} \mathrm{C}$ ages were used to construct the sequence with a 5-yr resolution.

Table $1{ }^{14} \mathrm{C}$ results of a Japanese cedar timber from the pumice flow deposit of Kawagodaira Volcano, Izu Peninsula (Japan).

\begin{tabular}{|c|c|c|c|c|c|c|c|}
\hline \multirow[b]{2}{*}{$\begin{array}{l}\text { Sample } \\
\text { ID }\end{array}$} & \multirow{2}{*}{$\begin{array}{l}\text { Ring nr } \\
\text { from } \\
\text { outer }\end{array}$} & \multicolumn{3}{|c|}{${ }^{14} \mathrm{C}$ age (BP) } & \multirow[b]{2}{*}{$\begin{array}{l}\text { Calibrated age } \\
\text { (cal BC, } 2 \sigma)\end{array}$} & \multirow{2}{*}{$\begin{array}{l}\text { Wiggle- } \\
\text { match age } \\
(\text { cal BC, } 2 \sigma)\end{array}$} & \multirow[b]{2}{*}{$\begin{array}{c}\text { Individual } \\
\text { agreement }\end{array}$} \\
\hline & & $\begin{array}{l}1 \mathrm{st} \\
\text { batch }\end{array}$ & $\begin{array}{l}\text { 2nd } \\
\text { batch }\end{array}$ & $\begin{array}{l}\text { Weighted } \\
\text { mean }\end{array}$ & & & \\
\hline Kg01 & $1-5$ & $3051 \pm 48$ & $2938 \pm 33$ & $2974 \pm 27$ & $1311-1116$ & $1212-1189$ & 121 \\
\hline Kg02 & $6-10$ & $2955 \pm 50$ & $3011 \pm 37$ & $2991 \pm 30$ & $1371-1126$ & $1217-1194$ & 101 \\
\hline $\mathrm{Kg} 03$ & $11-15$ & $2878 \pm 48$ & $2946 \pm 40$ & $2918 \pm 31$ & $1255-1013$ & $1222-1199$ & $59^{\mathrm{a}}$ \\
\hline Kg04 & $16-20$ & $3006 \pm 46$ & $2973 \pm 34$ & $2984 \pm 28$ & $1369-1122$ & $1227-1204$ & 133 \\
\hline Kg05 & $21-25$ & $2951 \pm 46$ & $2933 \pm 34$ & $2940 \pm 27$ & $1260-1051$ & $1232-1209$ & $47^{\mathrm{a}}$ \\
\hline Kg06 & $26-30$ & $2998 \pm 48$ & $2979 \pm 36$ & $2979 \pm 29$ & $1370-1116$ & $1237-1214$ & 129 \\
\hline Kg07 & $31-35$ & $2936 \pm 47$ & $2985 \pm 35$ & $2968 \pm 28$ & $1307-1057$ & $1242-1219$ & 102 \\
\hline Kg08 & $36-40$ & $3041 \pm 45$ & $3008 \pm 36$ & $3020 \pm 28$ & $1389-1133$ & $1247-1224$ & 82 \\
\hline Kg09 & $41-45$ & $3043 \pm 46$ & $2978 \pm 34$ & $3001 \pm 27$ & $1374-1129$ & $1252-1229$ & 118 \\
\hline $\mathrm{Kg} 10$ & $46-50$ & $2982 \pm 48$ & $2959 \pm 35$ & $2967 \pm 28$ & $1305-1057$ & $1257-1234$ & 125 \\
\hline $\mathrm{Kg} 11^{\mathrm{b}}$ & $51-55$ & $2971 \pm 49$ & $2828 \pm 36^{\mathrm{b}}$ & & & & \\
\hline Kg12 & $56-60$ & $2997 \pm 49$ & $2959 \pm 34$ & $2970 \pm 28$ & $1309-1058$ & $1267-1244$ & 122 \\
\hline Kg13 & $61-65$ & $2971 \pm 49$ & $2979 \pm 34$ & $2976 \pm 28$ & $1368-1115$ & $1272-1249$ & 117 \\
\hline Kg14 & $66-70$ & $3023 \pm 46$ & $2972 \pm 35$ & $2990 \pm 28$ & $1370-1127$ & $1277-1254$ & 128 \\
\hline $\mathrm{Kg} 15$ & $71-75$ & $3048 \pm 49$ & $3032 \pm 34$ & $3037 \pm 28$ & $1398-1213$ & $1282-1259$ & 108 \\
\hline Kg16 & $76-80$ & $3014 \pm 46$ & $2982 \pm 33$ & $2993 \pm 27$ & $1370-1128$ & $1287-1264$ & 100 \\
\hline Kg17 & $81-85$ & $3060 \pm 44$ & $2973 \pm 35$ & $3006 \pm 27$ & $1377-1130$ & $1292-1269$ & 137 \\
\hline Kg18 & $86-90$ & $3013 \pm 46$ & $3070 \pm 34$ & $3050 \pm 27$ & $1406-1222$ & $1297-1274$ & 82 \\
\hline Kg19 & $91-95$ & $3021 \pm 52$ & $3021 \pm 36$ & $3021 \pm 29$ & $1389-1133$ & $1307-1284$ & 144 \\
\hline Kg20 & 96-100 & $3100 \pm 45$ & $3002 \pm 36$ & $3041 \pm 28$ & $1401-1215$ & $1312-1289$ & 122 \\
\hline Kg21 & $101-105$ & $3099 \pm 48$ & $3050 \pm 33$ & $3066 \pm 27$ & $1409-1267$ & $1317-1294$ & 76 \\
\hline Kg22 & $106-110$ & $3037 \pm 49$ & $3072 \pm 31$ & $3090 \pm 26$ & $1427-1299$ & $1322-1299$ & $40^{\mathrm{a}}$ \\
\hline Kg23 & $111-115$ & $3055 \pm 46$ & $3062 \pm 37$ & $3059 \pm 28$ & $1411-1262$ & 1327-1304 & 116 \\
\hline Kg24 & $116-120$ & $3106 \pm 45$ & $3072 \pm 35$ & $3085 \pm 28$ & $1425-1272$ & 1332-1309 & 100 \\
\hline Kg25 & $121-125$ & $3170 \pm 47$ & $3031 \pm 32$ & $3075 \pm 26$ & $1414-1269$ & $1337-1314$ & 128 \\
\hline Kg26 & $126-130$ & $3148 \pm 49$ & $3090 \pm 35$ & $3109 \pm 28$ & $1438-1310$ & $1342-1319$ & 95 \\
\hline Kg27 & $131-135$ & $3052 \pm 48$ & $3119 \pm 32$ & $3098 \pm 27$ & $1431-1308$ & $1347-1324$ & 107 \\
\hline Kg28 & $136-140$ & $3060 \pm 45$ & $3023 \pm 32$ & $3035 \pm 26$ & 1394-1214 & 1352-1329 & 83 \\
\hline
\end{tabular}

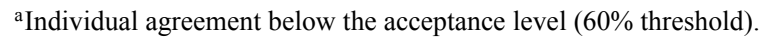

${ }^{\mathrm{b}} \mathrm{Kg} 11$ was excluded from the wiggle-matching due to the statistical difference between duplicate measurements.

The wiggle-match estimate calculated that the Kawagodaira eruption took place in 1210-1187 cal $\mathrm{BC}$. The overall series $\mathrm{OxCal}$ agreement index $\left(\mathrm{A}_{\text {comb }}\right)$ proved to be satisfactory $(100.3 \%$ above the acceptance level of $13.9 \%$ ). Yet, 3 of the 27 data (Kg03, $\mathrm{Kg} 05$, and $\mathrm{Kg} 22)$ suggested that the individual agreement index for OxCal was below the acceptance level (60\% threshold) (Bronk Ramsey et al. 2004). After we excluded these 3 data as outliers, the date range of the Kawagodaira volcanic eruption remained nearly the same, $1209-1188 \mathrm{cal} \mathrm{BC}(95.4 \%$ confidence level). The overall series agreement index for OxCal was much higher; $\mathrm{A}_{\text {comb }}=158.3 \%$ above the acceptance level $\left(\mathrm{A}_{\text {comb }}=\right.$ 


\section{S Tani et al.}

$14.4 \%)$. The 2 estimates gave exactly the same age (1198.5 cal BC in the median value). We thus concluded that the Kawagodaira volcanic eruption occurred in 1210-1187 cal BC.

In Figure $2,{ }^{14} \mathrm{C}$ data used for wiggle-matching were plotted on the estimated calendar age with the data sets of IntCal09 and IntCal98 (which was less smoothed than the IntCal09 curve). All the data correspond with the IntCal data sets within $2 \sigma$ uncertainty ( $1 \sigma$ uncertainty in Figure 2). Based on Anatolian trees (Manning et al. 2010) and German oak (Manning et al. 2009; Kromer et al. 2010), potential age offsets from IntCal around 1325 and $1225 \mathrm{BC}$ have been discussed. Although we need much higher precision and accuracy measurements to confirm the age offset, the systematic offset from the IntCal data sets was not clear for sample Kg. According to Nakamura et al. (2007), the local age offsets for Japanese wood samples from IntCal09 were 26.2, 14.9, and $7.8{ }^{14} \mathrm{C}$ yr for AD $881-$ $1072,1413-1615$, and $1617-1739$, respectively. The weighted average of these values was $17.4{ }^{14} \mathrm{C}$ yr towards older ages. Hong et al. (2013) also showed a similar consistent age offset of $17.2{ }^{14} \mathrm{C} \mathrm{yr}$ based on annual-resolution ${ }^{14} \mathrm{C}$ analyses of known-age Korean woods from AD 1250-1650. Other reports have presented complementary evidence, including an age offset of 30-40 yr in the period around AD 100-200 (Sakamoto et al. 2003) and an age offset of $14 \pm 7^{14} \mathrm{C}$ yr by wiggle-matching of known-age wooden artifacts (Imamura et al. 2007). Some research, however, also reported no age offset for Japanese wood samples from IntCal09 over the long period from $820 \mathrm{BC}$ to AD 900 (Sakamoto et al. 2003; Ozaki et al. 2007). The 140-yr-long data set of sample Kg beginning $1340 \mathrm{BC}$ corresponded well to the wiggles of the ${ }^{14} \mathrm{C}$ calibration curve, and did not show any systematic age offsets.

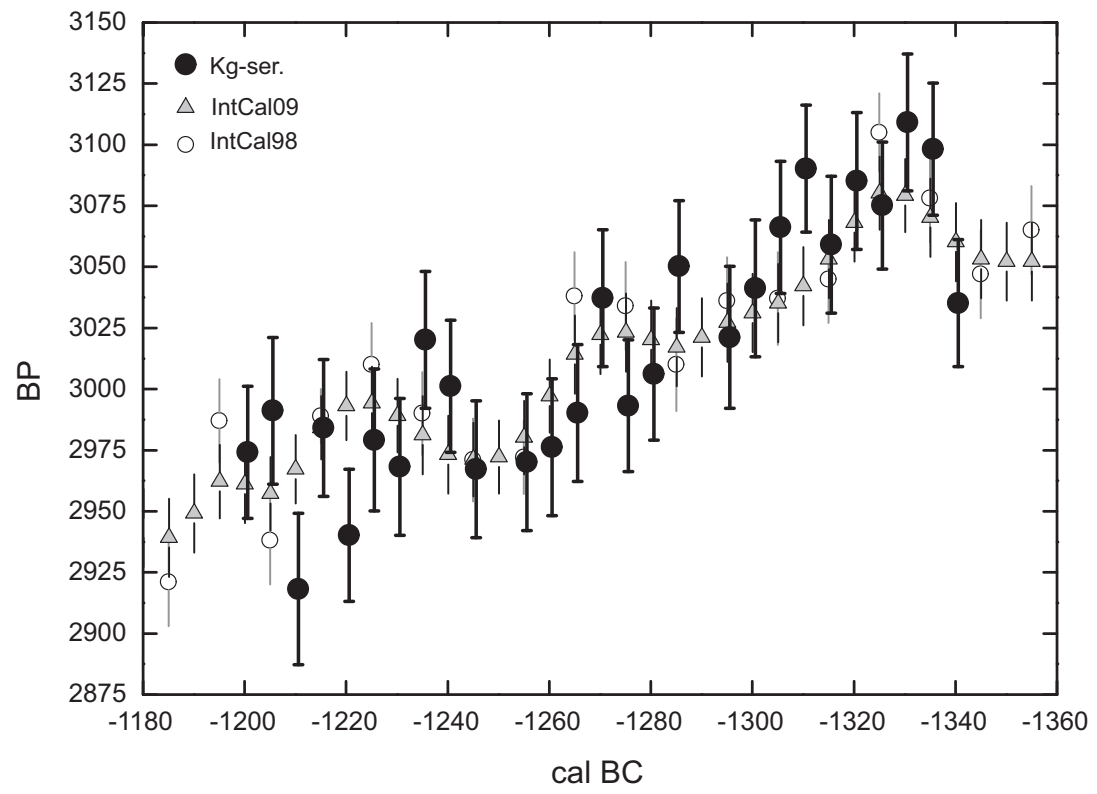

Figure 2 Wiggle-matching of ${ }^{14} \mathrm{C}$ data ( $1 \sigma$ error bars) of fossil Japanese cedar collected on the north slope of Kawagodaira Volcano against the Northern Hemisphere ${ }^{14} \mathrm{C}$ calibration data sets IntCa198 (Stuiver et al. 1998) and IntCal09 (Reimer et al. 2009) using OxCal v 4.1 (Bronk Ramsey 2009).

\section{CONCLUSIONS}

We determined the eruption age of Kawagodaira Volcano by performing ${ }^{14} \mathrm{C}$ wiggle-matching analysis of a Japanese cedar timber excavated from the pyroclastic flow deposit of Kawagodaira Vol- 
cano. The data set from sample $\mathrm{Kg}$ agreed well with the ${ }^{14} \mathrm{C}$ calibration data of IntCal09. We thus conclude that the Kawagodaira Volcano eruption took place in 1210-1187 cal BC, at the end of the late Jomon period (2000-1000 BC). The white pumice layer from Kawagodaira Volcano is a key for understanding the cultural evolution in the transition from the late to final Jomon culture in Japan.

\section{ACKNOWLEDGMENTS}

We wish to thank Professor Hideki Wada of Shizuoka University for collecting the fossil Japanese cedar and Yuriko Hibi of Nagoya University for helping in laboratory work. Thanks are also due to all the staff of the KIGAM AMS laboratory for the AMS ${ }^{14} \mathrm{C}$ measurements.

\section{REFERENCES}

Bronk Ramsey C. 2009. Bayesian analysis of radiocarbon dates. Radiocarbon 51(1):337-60.

Bronk Ramsey C, Manning SW, Galimberti M. 2004. Dating the volcanic eruption at Thera. Radiocarbon 46(2):325-44.

Hong W, Park JH, Sung KS, Woo HJ, Kim JK, Choi HW, Kim GD. 2010. A new 1MV AMS facility at KIGAM. Radiocarbon 52(2-3):243-51.

Hong W, Park JH, Park WK, Sung KS, Lee KH, Park G, Kim YE, Kim JK, Choi HW, Kim GD, Woo HJ, Nam TG. 2013. Calibration curve from AD 1250 to AD 1650 by measurements of tree-rings grown on the Korean peninsula. Nuclear Instruments and Methods in Physics Research B 294:435-9.

Imamura M, Ozaki H, Mitsutani T, Niu E, Itoh S. 2007. Radiocarbon wiggle-matching of Japanese historical materials with a possible systematic age offset. Radiocarbon 49(2):331-7.

Kigoshi K, Endo K. 1963. Gakushuin natural radiocarbon measurements II. Radiocarbon 5:109-17.

Kromer B, Manning SW, Friedrich M, Talamo S, Trano N. $2010 .{ }^{14} \mathrm{C}$ calibration in the 2 nd and 1 st millennia BC-Eastern Mediterranean Radiocarbon Comparison Project (EMRCP). Radiocarbon 52(3):875-86.

Machida H, Arai F. 1992. Atlas of Tephra in and Around Japan. Tokyo: University of Tokyo Press. In Japanese.

Manning SW, Pulak C, Kromer B, Talamo S, Bronk Ramsey C, Dee M. 2009. Absolute age of the Uluburun shipwreck: a key Late Bronze Age time-capsule for the East Mediterranean. In: Manning SW, Bruce MJ, editors. Tree-Rings, Kings and Old World Archaeology and Environment: Papers Presented in Honor of Peter Ian Kuniholm. Oxford: Oxbow Books. p 163-87.

Manning SW, Kromer B, Bronk Ramsey C, Pearson CL, Talamo S, Trano N, Watkins DJ. 2010. ${ }^{14} \mathrm{C}$ record and wiggle-match placement for the Anatolian (Gordion area) juniper tree-ring chronology $\sim 1729$ to $751 \mathrm{cal}$ BP, and typical Aegean/Anatolian (growing season related) regional ${ }^{14} \mathrm{C}$ offset assessment. Radiocarbon 52(4):1571-97.

Nakamura T, Miyahara H, Masuda M, Menjo H, Kuwana K, Kimura K, Okuno M, Minami M, Oda H, Rakowski A, Ohta T, Ikeda A, Niue E. 2007. High precision ${ }^{14} \mathrm{C}$ measurements and wiggle-match dating of tree rings at Nagoya University. Nuclear Instruments and Methods in Physics Research B 259(1):408-13.

Ozaki H, Imamura M, Matsuzaki H, Mitsutani T. 2007. Radiocarbon in 9th to 5th century BC tree-ring samples from the Ouban 1 archaeological site, Hiroshima, Japan. Radiocarbon 49(2):473-9.

Reimer PJ, Baillie MGL, Bard E, Bayliss A, Beck JW, Blackwell PG, Bronk Ramsey C, Buck CE, Burr GS, Edwards RL, Friedrich M, Grootes PM, Guilderson TP, Hajdas I, Heaton T, Hogg AG, Hughen KA, Kaiser KF, Kromer B, McCormac FG, Manning SW, Reimer RW, Richards DA, Southon JR, Talamo S, Turney CSM, van der Plicht J, Weyhenmeyer CE. 2009. IntCal09 and Marine09 radiocarbon age calibration curves, 0-50,000 years cal BP. Radiocarbon 51(4): 1111-50.

Sakamoto M, Imanura M, van der Plicht J, Mitsutani T. Sahara M. 2003. Radiocarbon calibration for Japanese wood samples. Radiocarbon 45(1):81-9.

Shimada S. 2000. Eruption of the Amagoi-Kawagodaira volcano and paleo-environments in the late and latest period around Izu Peninsula. Quaternary Research 39(2):151-64. In Japanese with English abstract.

Stuiver M, Polach HA. 1977. Discussion: reporting of ${ }^{14} \mathrm{C}$ data. Radiocarbon 19(3):355-63.

Stuiver M, Reimer, PJ, Bard E, Beck JW, Burr GS, Hughen KA, Kromer B, McCormac G, van der Plicht J, Spurk M. 1998. INTCAL98 radiocarbon age calibration, 24,000-0 cal BP. Radiocarbon 40(3):1041-83.

Takemura K, Kitagawa H, Hayashida A, Yaduda Y. 1994 Sedimentary facies and chronology of core samples from Lake Mikata, Lake Suigetsu and Kurota Lowland, central Japan - sedimentary environment in Mikata Lowland since the last interglacial time. Journal of Geography 103(3):233-42. In Japanese with English abstract.

Takemura K, Iwabe C, Hayashida A, Danhara T, Kitagawa H, Haraguchi T, Sato T, Ishikawa N. 2010. Stratigraphy of marker tephras and sediments during the past 50,000 years from multiple sites in Lake Biwa, Japan. Quaternary Research 49(3):147-60. In Japanese with English abstract. 